\title{
In Vitro Effect and Mechanism of Action of Ergot Alkaloid Dihydroergocristine in Chemoresistant Prostate Cancer Cells
}

\author{
LIJUAN BAI ${ }^{1,2}$, XIN LI $^{2,3}$, XIAOWEI MA ${ }^{2,4}$, RUI ZHAO $^{2,5}$ and DAQING WU ${ }^{2,3}$ \\ ${ }^{1}$ Department of Geriatrics, Union Hospital, Tongji Medical College, \\ Huazhong University of Science and Technology, Wuhan, P.R. China; \\ ${ }^{2}$ Molecular Oncology and Biomarkers Program, Georgia Cancer Center, \\ and Department of Biochemistry and Molecular Biology, Medical College of Georgia, \\ Augusta University, Augusta, GA, U.S.A.; \\ ${ }^{3}$ Center for Cancer Research and Therapeutic Development and Department of Biological Sciences, \\ Clark Atlanta University, Atlanta, GA, U.S.A.; \\ ${ }^{4}$ Department of Clinical Laboratory, Renji Hospital, School of Medicine, \\ Shanhhai Jiao Tong University, Shanghai, P.R. China; \\ ${ }^{5}$ Department of Urology, China-Japan Union Hospital of Jilin University, Changchun, P.R. China
}

\begin{abstract}
Background/Aim: Chemoresistance is a major obstacle in the treatment of prostate cancer (PCa). It is imperative to develop novel strategies for overcoming chemoresistance and improving clinical outcomes. We evaluated the in vitro activity and mechanism of action of dihydroergocristine (DHECS), an ergot alkaloid approved for the treatment of dementia, in PCa cells. Materials and Methods: The in vitro effects of DHECS on PCa cell cycle and viability were determined by flow cytometry and colorimetric assay. The effects of DHECS on PCa cell signaling were evaluated by quantitative PCR, western blot analysis and reporter assay. Results: DHECS was effective in inducing cell cycle arrest and apoptosis in human PCa cells. Of particular interest, DHECS demonstrated high potency against chemoresistant PCa cells. At the molecular level, DHECS affected multiple factors implicated in the regulation of cancer cell cycle and programmed cell death, including p53, mouse double minute 2 homolog (MDM2), retinoblastoma protein $(R B), p 21$, E2F transcription factor 1 (E2F1), survivin, myeloid cell leukemia 1 (Mcl-1) and poly ADP ribose polymerase (PARP). Furthermore, DHECS may function through dopamine
\end{abstract}

This article is freely accessible online.

Correspondence to: Drs. Daqing Wu or Xin Li, Center for Cancer Research and Therapeutic Development and Department of Biological Sciences, Clark Atlanta University, Atlanta, GA 30314, U.S.A. Tel: +1 4048806337, e-mail: dwu@cau.edu orxli@cau.edu

Key Words: Prostate cancer, chemoresistance, dihydroergocristine mesylate, dopamine receptor agonist. receptor-mediated effects on 5'-AMP-activated protein kinase $(A M P K)$ and nuclear factor kappa $B(N F-k B)$. Conclusion: DHECS has the potential to be repurposed as a novel anticancer agent for the management of chemoresistant PCa.

Prostate cancer (PCa) is the most commonly diagnosed cancer and the second leading cause of cancer-related death among men in the United States (1). Docetaxel, the first-line standard chemotherapy for metastatic $\mathrm{PCa}$, initially prolongs overall survival by 3 to 4 months; however, most patients relapse and become chemoresistant without a cure $(2,3)$. It is imperative to develop novel strategies to overcome chemoresistance and improve clinical outcomes in PCa patients.

As a metabolite of tyrosine, dopamine acts as both a neurotransmitter and a hormone, and plays important roles in numerous physiological processes, such as voluntary movement and sympathetic regulation $(4,5)$. Dopaminergic dysfunction results in multiple human diseases including Parkinson's disease (6), Huntington's disease (7) and depression (8). The physiological and pathological functions of dopamine are thought to be mediated by at least five distinct dopamine receptors, which belong to the $\mathrm{G}$ protein-coupled receptors (GPCRs) superfamily. Based on their downstream effects on adenosine 3',5'-cyclic monophosphate (cAMP) signaling, dopamine receptors can be classified into D1-like (D1, D5) and D2-like (D2, D3, D4) classes (9). D1-like dopamine receptors stimulate cAMP production and protein kinase A (PKA) activity through coupling to $\mathrm{G} \alpha_{\mathrm{s} / \text { olf }}$ proteins, whereas D2-like dopamine receptors suppress cAMP production and PKA activity through coupling to $\mathrm{G} \alpha_{\mathrm{i} / \mathrm{o}}$ proteins (10). In addition to their classical roles in cAMP signaling, dopamine receptors regulate diverse molecular pathways via $\mathrm{G}$ 
Table I. Sequences of PCR primers.

\begin{tabular}{lll}
\hline Gene & Forward primer & Reverse primer \\
\hline Survivin & TGCCCCGACGTTGCC & CAGTTCTTGAATGTAGAGATGCGGT \\
GAPDH & CGAGATCCCTCCAAAATCAA & TTCACACCCATGACGAACAT \\
\hline
\end{tabular}

protein-dependent or -independent mechanisms. For example, D1-like dopamine receptors or D1/D2 receptor heterodimers regulate diacylglycerol (DAG) and inositol 1,4,5-trisphosphate (IP3) signaling via $\mathrm{G \alpha q}$ proteins $(11,12)$. The formation of D2-like dopamine receptors/ $\beta$-arrestin2/protein phosphatase 2A (PP2A)/Akt complex leads to PP2A-mediated Akt deactivation and glycogen synthase kinase-3 (GSK-3) activation (13). D2like dopamine receptors are involved in the regulation of intracellular calcium levels by modulating $\mathrm{G}_{\beta \gamma}$ signaling (14), and D1 and D2-like receptors differentially affect mitogenactivated protein kinases (MAPKs) signaling $(15,16)$.

Dihydroergocristine (DHECS) is a dihydrogenated alkaloid of ergot (17) that mainly affects several neurological processes, including memory (18-20), cerebral hypoxia (21), sleepwakefulness cycle (22) and prolactin release $(23,24)$. DHECS has been used, alone or combined with other ergot alkaloids, in the treatment of Parkinson's disease (25), peripheral vascular diseases (26), hypertension (27), hyperprolactinemia (28) and depression (29). Although the exact mechanisms underlying these clinical benefits remain to be fully understood, it has been proposed that DHECS acts as an agonist or antagonist of two specific groups of GPCRs, i.e., dopaminergic receptors and adrenergic receptors (30). For example, DHECS-induced inhibition of prolactin release and cAMP accumulation can be abolished by D2 receptor (DRD2) antagonists haloperidol and pimozide (23). In anterior pituitary cells, DHECS and bromocriptine, a DRD2 agonist, inhibit angiotensin IImedicated release of fatty acids, an effect that is completely blocked by the selective D2 receptor antagonist sulpiride (31).

Accumulating evidence from various experimental models has implicated a molecular connection between the dysregulation of dopamine receptor biology and human cancers (32-34). In a recent study, we provided the first evidence demonstrating that DRD2 expression is inversely associated with clinical PCa progression. We further identified bromocriptine, a semisynthetic ergot alkaloid, as a potential adjunct therapy to sensitize PCa cells to docetaxel chemotherapy (35). These observations supported the notion that DRD2 agonism may represent a novel strategy to overcome chemoresistance. In this study, we report that DHECS exhibits in vitro cytotoxicity in a panel of established PCa cell lines, and intriguingly, demonstrates high specificity against chemoresistant PCa cells by affecting multiple oncogenic signals involved in cancer cell survival and proliferation.

\section{Materials and Methods}

Cell culture and chemicals. Human PCa cell lines LNCaP and C42 were obtained from Dr. Leland WK Chung (Cedars-Sinai Medical Center, Los Angeles, CA, USA) and maintained in Tmedium (Life Technologies, Carlsbad, CA, USA) supplemented with 5\% fetal bovine serum (FBS; Atlanta Biologicals, Atlanta, GA, USA). PC-3 cell line was obtained from American Type Culture Collection (ATCC) and maintained in RPMI1640 medium (Thermo Fisher Scientific) supplemented with 10\% FBS. CWR22Rv1 cell line was obtained from Dr. Jin-Tang Dong (Emory University, Atlanta, GA, USA), and maintained in RPMI1640 medium supplemented with 10\% FBS, $4.5 \mathrm{~g} / 1$ glucose, $1.5 \mathrm{~g} / 1$ sodium bicarbonate, $10 \mathrm{mmol} / 1$ sodium pyruvate, and 10 mmol/l HEPES. ARCaP ${ }_{E}$ cells stably expressing control short hairpin RNA (shRNA) ( $\mathrm{ARCaP}_{\mathrm{E}^{-}}$shCtrl) or human EPLIN shRNA $\left(\mathrm{ARCaP}_{\mathrm{E}^{-}}\right.$-shEPLIN) were established and maintained as described in our previous publication (36). C4-2B and its docetaxel-resistant derivative C4-2B-TaxR subline (37) were originally provided by Dr. Allen C. Gao (University of California Davis) and cultured following the procedures described in (37), with the modification that $\mathrm{C} 4-2 \mathrm{~B}-\mathrm{TaxR}$ cells were routinely maintained in the presence of $100 \mathrm{nM}$ docetaxel (LC Laboratories, Woburn, MA, USA). The final concentration of docetaxel in culture medium was reduced to $5 \mathrm{nM}$ before experimental assays. KB-3-1 and its vinblastineresistant derivative KB-V1 were obtained from Zhuo G. Chen (Emory University) and maintained as described previously (38). Dimethyl sulfoxide (DMSO) was purchased from Sigma-Aldrich (St. Louis, MO, USA). DHECS was obtained from Santa Cruz Biotechnology, Inc (Santa Cruz, CA, USA).

Cell viability assay. In vitro cytotoxicity was measured using Cell Counting Kit-8 (CCK-8; Dojindo Molecular Technologies, Inc., Rockville, MD, USA) according to the manufacturer's instruction. Half maximal inhibitory concentration $\left(\mathrm{IC}_{50}\right)$ was calculated using SigmaPlot program (Systat Software Inc., San Jose, CA, USA).

Apoptosis and cell cycle assays. For apoptosis assay, C4-2BTaxR cells were incubated with DHECS at varying concentrations for $72 \mathrm{~h}$, and then stained with an APC Annexin $\mathrm{V}$ apoptosis detection kit (BioLegend, San Diego, CA, USA) according to the manufacturer's instruction. For cell cycle assay, cells were serum-starved for $24 \mathrm{~h}$ and incubated with DHECS at varying concentrations for $48 \mathrm{~h}$, then stained with propidium iodide (PI, Sigma-Aldrich) $(50 \mu \mathrm{g} / \mathrm{ml})$ according to standard procedures. Both apoptosis and the distribution of cells in the cell cycle were analysed by flow cytometry with FACSCanto II flow cytometer (BD Biosciences, Bedford, MA, USA). The results were analyzed by FlowJo software (Tree Star, Inc., Ashland, OR, USA). 
Quantitative PCR ( $q P C R$ ). Total RNA was extracted using Qiagen RNeasy Kit (Valencia, CA, USA). cDNA was synthesized using SuperScript ${ }^{\circledR}$ III First-Strand Synthesis System (Life Technologies). qPCR was performed by the Stratagene Mx3005P system (Agilent technologies) using PowerSYBR ${ }^{\circledR}$ Green PCR Master Mix (Thermo Fisher Scientific) according to the manufacturer's instruction. Primers used for qPCR are listed in Table I.

Western blot analysis. Total cell lysates were extracted using radioimmunoprecipitation (RIPA) buffer (Santa Cruz Biotechnology). Halt ${ }^{\mathrm{TM}}$ protease inhibitor cocktail (Thermo Fisher Scientific) was added to the total cell lysates. Immunoblotting analyses were performed according to standard procedures (Bio-Rad Bulletin 6376, Bio-Rad, Hercules, CA, USA). Primary antibodies used in immunoblotting are listed in Table II.

Transfection and reporter assay. Human survivin promoter reporters pSurvivin-Luc1430 and pSurvivin-Luc230 (39) were provided by Dr. Allen C. Gao. pRL-TK was purchased from Promega (Madison, WI, USA). Lipofectamine 3000 reagent (Life Technologies) was used for cDNA transfection according to the manufacturer's instructions. Twenty-four hours after transfection, C4-2B-TaxR cells were treated with DHECS at the indicated concentrations for $48 \mathrm{~h}$. Cell lysates were extracted and luciferase activities were measured using a Dual-Luciferase reporter assay system (Promega). Relative luciferase units were defined as firefly luciferase intensity normalized to Renilla luciferase activity.

\section{Results}

DHECS inhibits the in vitro viability of PCa cells and demonstrates selectivity against chemoresistant PCa cells. We first determined the in vitro cytotoxicity of DHECS in several established PCa cell lines, including LNCaP [androgendependent, androgen receptor (AR)-positive], C4-2 (androgenindependent, AR-positive), CWR22Rv1 [androgenindependent, AR- and AR variant 7 (AR-V7)-positive] and PC3 (AR-negative). Although these cell lines have distinct molecular profiles and phenotypes, they are sensitive to docetaxel treatment in cellular cultures. As shown in Figure 1A, DHECS exhibited various degrees of cytotoxicities in these cells, with the $\mathrm{IC}_{50}$ value of $25.78 \mu \mathrm{M}$ in $\mathrm{LNCaP}, 25.31 \mu \mathrm{M}$ in C4-2, $13.44 \mu \mathrm{M}$ in CWR22Rv1 and $10.63 \mu \mathrm{M}$ in PC-3 cells.

We further examined the in vitro cytotoxicity of DHECS in two newly established models of chemoresistant PCa. Our previous work has demonstrated that the depletion of epithelial protein lost in neoplasm (EPLIN) in a low-invasive, epitheliallike PCa line $\mathrm{ARCaP}_{\mathrm{E}}$ promotes epithelial-to-mesenchymal transition (EMT), increases invasiveness and stemness, and confers chemoresistance $(36,40)$. These results allowed us to propose that EPLIN-depleted $\mathrm{ARCaP}_{\mathrm{E}}$ cells $\left(\mathrm{ARCaP}_{\mathrm{E}^{-}}\right.$ shEPLIN) represent a subpopulation of inherently chemoresistant PCa cells. Interestingly, DHECS demonstrated potent cytotoxicity in $\mathrm{ARCaP}_{\mathrm{E}^{-}}$-shEPLIN cells $\left(\mathrm{IC}_{50}=3.28 \mu \mathrm{M}\right)$ but showed much weaker activity in the chemosensitive counterpart $\mathrm{ARCaP}_{\mathrm{E}^{-}}$shCtrl expressing control shRNAs
Table II. Antibodies.

\begin{tabular}{lcc}
\hline Antibody & Catalog number & Source \\
\hline$\beta$-actin & 4970 & Cell Signaling Technology \\
Cleaved PARP & 5625 & Cell Signaling Technology \\
PARP & 9542 & Cell Signaling Technology \\
Survivin & NB500-201 & Novus Biologicals \\
MCL-1 & sc-819 & Santa Cruz Biotechnology \\
E2F1 & sc-56661 & Santa Cruz Biotechnology \\
P53 & sc-126 & Santa Cruz Biotechnology \\
p21 & 556430 & BD Medical Technology \\
p-RB/RB & sc-102 & Santa Cruz Biotechnology \\
MDM2 (Ab-6) & OP146 & EMD Millipore \\
p-MDM2 & 3521 & Cell Signaling Technology \\
DRD1 & 720276 & Invitrogen \\
DRD2 & sc-5303 & Santa Cruz Biotechnology \\
p-ERK & sc-7383 & Santa Cruz Biotechnology \\
ERK & sc-135900 & Santa Cruz Biotechnology \\
p-PP1 $\alpha$ & 2581 & Cell Signaling Technology \\
PP1 $\alpha$ & sc-271762 & Santa Cruz Biotechnology \\
p-CREB & 9191 & Cell Signaling Technology \\
CREB & sc-377154 & Santa Cruz Biotechnology \\
p-NF-kB & 3033 & Cell Signaling Technology \\
NF-kB & 8242 & Cell Signaling Technology \\
p-AKT & 4060 & Cell Signaling Technology \\
AKT & 9272 & Cell Signaling Technology \\
p-CaMKK2 & 12818 & Cell Signaling Technology \\
\hline & &
\end{tabular}

$\left(\mathrm{IC}_{50}=17.19 \mu \mathrm{M}\right)$. The selectivity index (SI) of DHECS, defined as the ratio of its $\mathrm{IC}_{50}$ in $\mathrm{ARCaP}_{\mathrm{E}^{-}}$-shCtrl versus that in $\mathrm{ARCaP}_{\mathrm{E}^{-}}$-shEPLIN cells, was determined as 5.24 (Figure 1B). These results suggested that DHECS appeared to be more potent against chemoresistant $\mathrm{PCa}$ cells. To confirm this observation, we determined the $\mathrm{IC}_{50}$ of DHECS in a highly docetaxel-resistant C4-2B-TaxR subline, which was established by incubating parental, chemosensitive C4-2B cells in the presence of gradually increasing doses of docetaxel (37), therefore representing a cellular model of acquired chemoresistance. Consistently, DHECS demonstrated a higher in vitro cytotoxicity in $\mathrm{C} 4-2 \mathrm{~B}-\mathrm{TaxR}$ cells $\left(\mathrm{IC}_{50}=11.25 \mu \mathrm{M}\right)$ than in $\mathrm{C} 4-2 \mathrm{~B}$ cells $\left(\mathrm{IC}_{50}>80 \mu \mathrm{M}\right)$, with a SI of more than 7.11 (Figure 1C). The high potency of DHECS in chemoresistant cancer cells was also observed in other cancer types. For example, DHECS effectively inhibited the viability of $\mathrm{KB}-\mathrm{V}-1$ cells, a HeLa derivative that is highly resistant to vinblastine (41) $\left(\mathrm{IC}_{50}=17.19 \mu \mathrm{M}\right)$ (Figure 1D). Taken together, these results indicated that DHECS has excellent in vitro activities in chemoresistant cancer cells.

DHECS induces cell cycle arrest and apoptosis in chemoresistant PCa cells. As a cellular model, C4-2B-TaxR cells closely recapitulated the clinical features of bone metastatic, chemoresistant PCa and were used to determine the effect and mechanism of action of DHECS in 
A

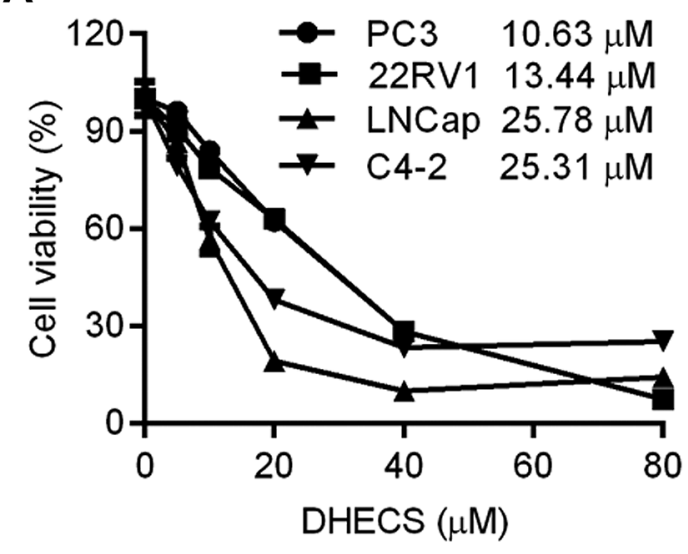

C

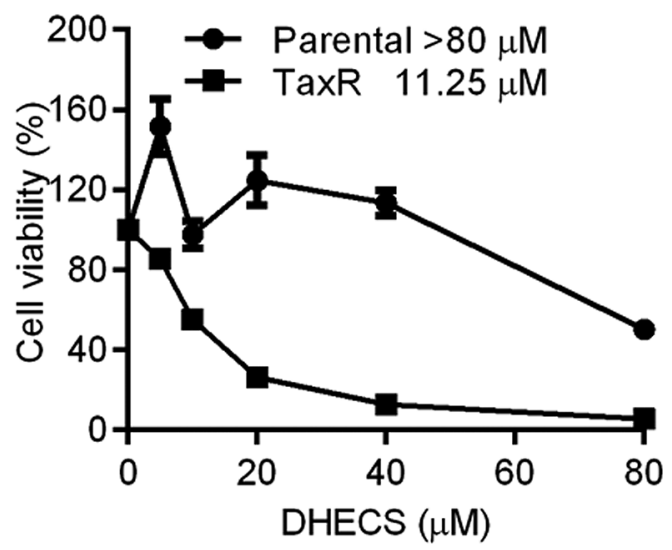

B

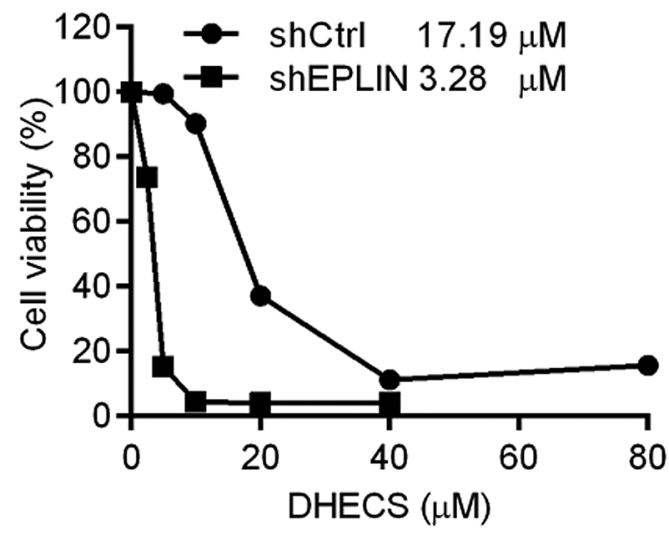

D

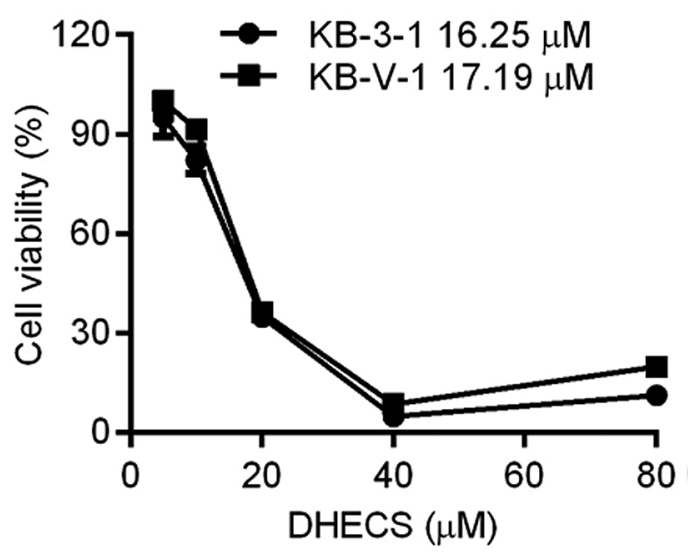

Figure 1. In vitro cytotoxicity of DHECS in prostate cancer (PCa) cells. (A) In vitro cytotoxicity of DHECS in established PCa cell lines (72 h). (B) In vitro cytotoxicity of DHECS in the ARCaPE chemoresistant PCa model (72 h). ARCaPE cells expressing EPLIN shRNAs (ARCaPE-shEPLIN) are resistant to docetaxel. (C) In vitro cytotoxicity of DHECS in the C4-2B chemoresistant model (72 h). C4-2B-TaxR cells are highly resistant to docetaxel. (D) In vitro cytotoxicity of DHECS in the KB-3-1 and its chemoresistant derivative KB-V1 cells (72 h).

chemoresistant PCa cells. Flow cytometry showed that DHECS significantly induced cell cycle arrest at the $G_{1} / S$ checkpoint and to a lesser degree, at the $\mathrm{G}_{2} / \mathrm{M}$ checkpoint, in a dose-dependent manner (Figure 2A). On the other hand, DHECS only markedly caused cell death at high concentrations (15 and $30 \mu \mathrm{M}$; Figure 2B).

Multiple factors are involved in the aberrant regulation of cell cycle in cancer cells (42). During $\mathrm{G}_{1} / \mathrm{S}$ transition, E2F transcription factor 1 (E2F1) activates the transcription of numerous S-phase proteins. Hypophosphorylated retinoblastoma protein $(\mathrm{RB})$ inhibits E2F1 function by binding to E2F1, whereas hyperphosphorylated RB (p-RB) releases E2F1 to active downstream genes $(43,44)$. The p53-p21 axis is responsible for the $\mathrm{G}_{1} / \mathrm{S}$ and $\mathrm{G}_{2} / \mathrm{M}$ arrest after DNA damage (45). Mouse double minute 2 homolog (MDM2), an ubiquitin ligase, promotes p53 ubiquitination and degradation (46). Since
DHECS mainly affected cell cycle at the $\mathrm{G}_{1} / \mathrm{S}$ checkpoint in chemoresistant $\mathrm{PCa}$ cells, we performed western blot analyses to examine the effect of DHECS on protein expression of the above cell cycle regulators. As summarized in Figure 2C, DHECS markedly suppressed the expression of E2F1 and p$\mathrm{RB}$, and increased p53 and p21 in a time-dependent manner. MDM2 phosphorylation (p-MDM2) was moderately inhibited by DHECS treatment, which might partially contribute to p53 upregulation (46). Taken together, these molecular changes are consistent with the inhibitory effect of DHECS on $G_{1} / S$ transition.

Survivin is the smallest member of the inhibitor of apoptosis (IAP) family and plays an essential role in cell survival. Myeloid cell leukemia 1 (Mcl-1) belongs to the BCL-2 family and is a critical anti-apoptotic protein. Previous studies from us and others have shown that overexpression of 
A

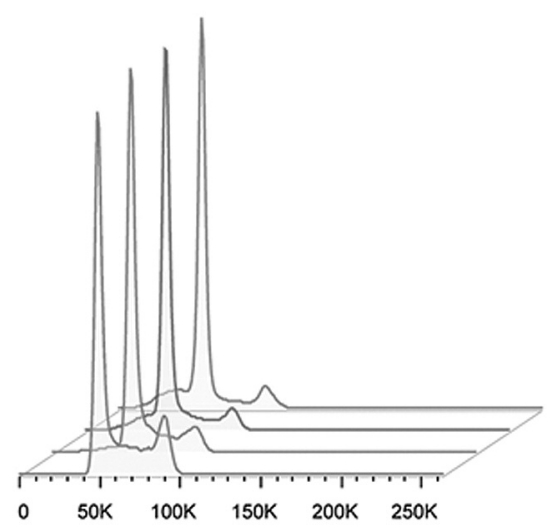

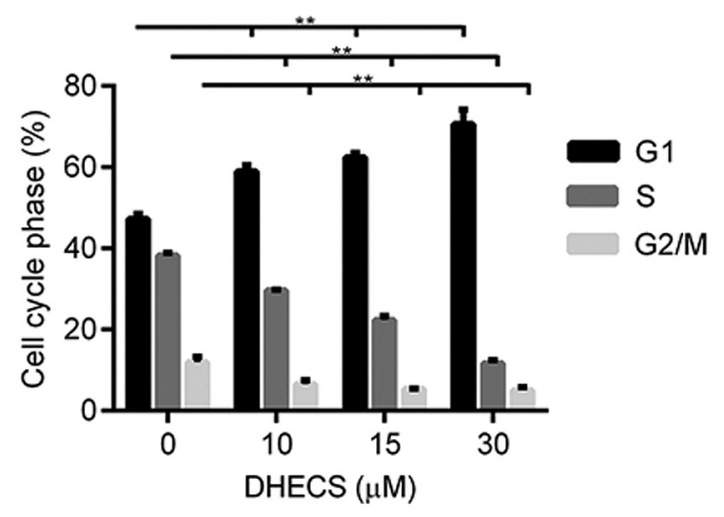

B

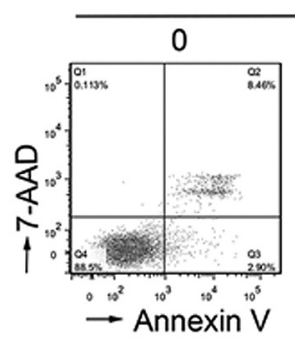

C

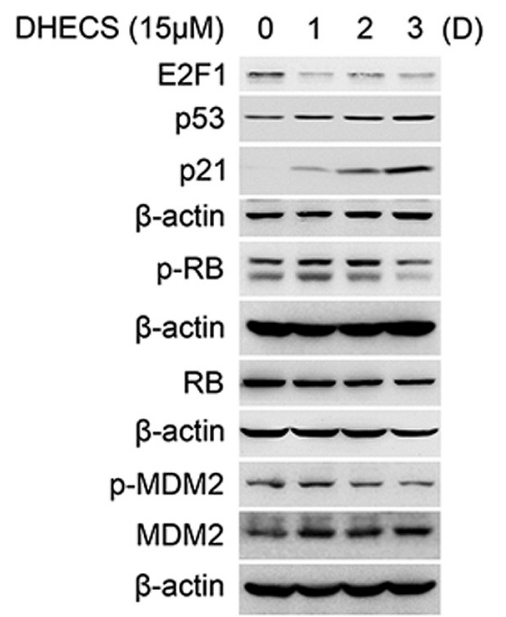

$\operatorname{DHECS}(\mu \mathrm{M})$
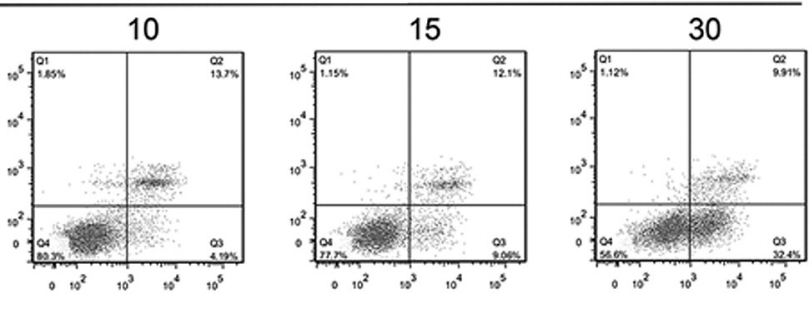

D

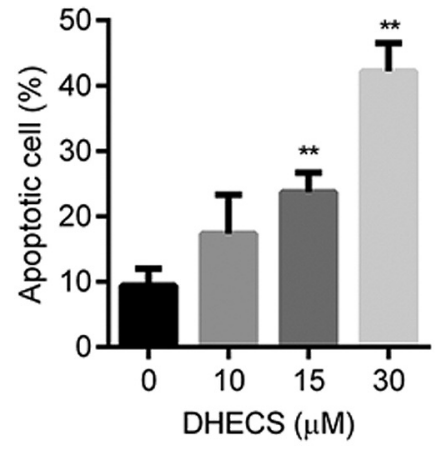

$$
\begin{aligned}
& \operatorname{DHECS}(10 \mu \mathrm{M}) \quad 0 \quad 1 \quad 2 \quad 3 \text { (D) } \\
& \text { Survivin } \\
& \beta \text {-actin } \\
& \text { MCL-1 } \\
& \beta \text {-actin } \\
& \operatorname{DHECS}(15 \mu \mathrm{M}) \quad 0 \quad 1 \quad 2 \quad 3 \text { (D) } \\
& \text { Cleaved PARP } \\
& \text { PARP }--- \\
& \beta \text {-actin - - - }
\end{aligned}
$$

Figure 2. Effects of DHECS on apoptosis and cell cycle in chemoresistant C4-2B-TaxR cells. (A) Flow cytometry analysis of the cell cycle in the docetaxel resistant C4-2B-TaxR cells treated with varying concentrations of DHECS $(48 \mathrm{~h}) . * * p<0.01$ for all pairwise comparisons between the percentages of cells in each cell cycle phase from the control and DHECSS treatment groups. (B) Flow cytometry assay of Annexin $V$ staining in C4-2B-TaxR cells treated with varying concentrations of DHECS $(72 \mathrm{~h}) .{ }^{* *} p<0.01$. (C) Western bot analysis on the expression of E2F1, $p 53, p 21$, $p-R B, R B, p-M D M 2$, and MDM2 1 in C4-2B-TaxR cells treated with DHECS $(15 \mu M)$ at the indicated time points. (D) Western bot analysis on the expression of survivin, MCL-1, cleaved PARP, and PARP in C4-2B-TaxR cells treated with DHECS at the indicated concentrations and time points.

both survivin and Mcl-1 is associated with clinical PCa metastasis and therapeutic resistance (47-50). As shown in Figure 2D, DHECS significantly reduced the expression of survivin and Mcl-1. Consistently, DHECS increased the cleavage of poly ADP ribose polymerase (PARP) in a timedependent manner. These results suggested that the inhibition of survivin and Mcl-1 may contribute to the pro-apoptosis effect of DHECS in chemoresistant PCa cells. 
A

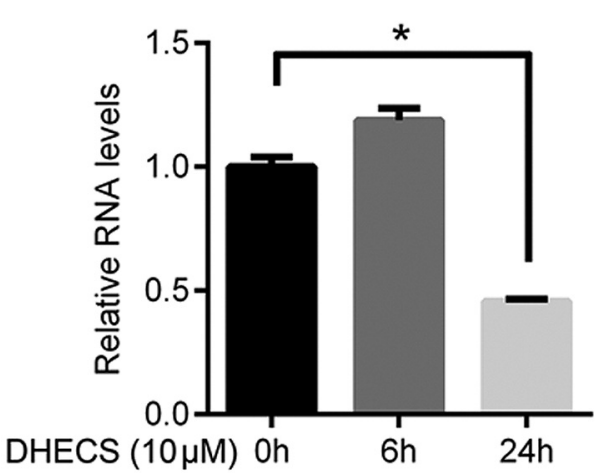

B

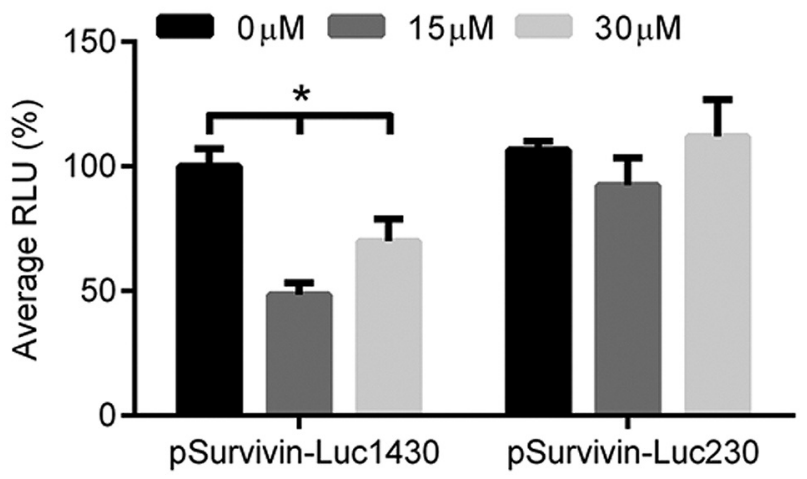

Figure 3. Effect of DHECS on survivin transcription in chemoresistant PCa cells. (A) qPCR analysis on the mRNA expression of survivin in C4$2 B$-TaxR cells treated with DHECS $(10 \mu M)$ at the indicated time points. (B) Relative luciferase activities of pSurvivin-Luc1430 and pSurvivinLuc230 in the docetaxel resistant C4-2B-TaxR cells treated with DHECS (48 h) at the indicated concentrations.

DHECS inhibits survivin expression at the transcriptional level. Given the important role of survivin in the control of cancer cell viability, we investigated whether DHECS regulates survivin expression at the transcriptional level. Quantitative PCR analyses showed that survivin mRNA was significantly downregulated at $24 \mathrm{~h}$ following DHECS treatment (Figure 3A). We further determined the effect of DHECS on the luciferase activity of two human survivin reporters, i.e., pSurvivin-Luc1430 that contains a 1,430-bp region of survivin promoter and pSurvivin-Luc230 that only contains a 230-bp truncated fragment of pSurvivin-Luc1430 (39). Interestingly, it appeared that DHECS significantly inhibited the luciferase activity of pSurvivin-Luc1430 reporter but not that of pSurvivin-Luc230 reporter (Figure 3B), indicating that DHECS may suppress survivin transcription via certain cis elements located within the 1,430-bp region and upstream of the 230-bp fragment of the survivin promoter (51).

DHECS affects the expression and downstream signaling of dopamine receptors. Since DHECS is a known activator of dopamine receptor signaling, we examined the effect of DHECS on the expression and signaling of two representative dopamine receptors in chemoresistant $\mathrm{PCa}$ cells. As shown in Figure 4A, DHECS slightly decreased DRD1 expression whereas moderately increased DRD2 expression in a time-dependent manner in C4-2B-TaxR cells, indicating that DHECS may differentially affect the expression of these two dopamine receptors in PCa cells.

To identify potential signaling pathways involved in the observed DHECS effects in chemoresistant PCa cells, we examined several major DRD1/DRD2 downstream signaling factors, i.e., cAMP response element-binding protein (CREB), extracellular signal-regulated protein kinase 1/2 (ERK1/2) and serine/threonine-protein phosphatase 1 (PP1 $\alpha$ )/AKT (52). As shown in Figure 4B, CREB phosphorylation at serine 133 was increased at a time point as early as $24 \mathrm{~h}$ following DHECS treatment. Phosphorylation of both ERK1/2 and PP1 $\alpha$ were markedly increased at $24 \mathrm{~h}$ but subsequently decreased between $48 \mathrm{~h}$ and $72 \mathrm{~h}$, with a slight reduction at $72 \mathrm{~h}$ when compared with the vehicle control. The endogenous level of total ERK1/2 kinases was moderately decreased from $24 \mathrm{~h}$, whereas total PP1 $\alpha$ expression was not affected by DHECS treatment. These results indicated that DHECS could activate cAMP signaling, inhibit MAPK activity on ERK1/2, and suppress PP1 $\alpha$ phosphorylation that may be partially responsible for the increased AKT phosphorylation.

The effect of DHECS on other putative dopamine receptor-mediated signaling pathways was also investigated (53-55). DHECS reduced the phosphorylation of calcium/calmodulin-dependent protein kinase kinase 2 (CaMKK2) at Ser511 and increased the phosphorylation of 5'-AMP-activated protein kinase (AMPK) at Thr172 in a time-dependent manner (Figure 4A), indicating that DHECS may also activate AMPK and augment its function as a tumor suppressor in chemoresistant $\mathrm{PCa}$ cells. Phosphorylation of nuclear factor kappa B (NF-kB), a transcriptional factor playing a crucial role in cancer progression (56), was significantly inhibited by DHECS (Figure 4B). Taken together, these results suggested that DHECS might exert its functions in PCa cells by affecting several dopamine receptor-related signaling pathways.

\section{Discussion}

Although our understanding of the biology of dopamine receptor signaling in cancer progression is still rudimentary and sometimes controversial, mounting experimental and clinical evidence has indicated that the dysregulation of 
A

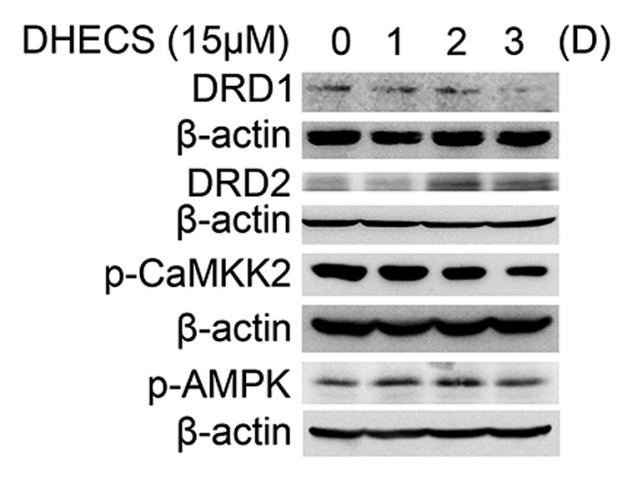

\section{B}

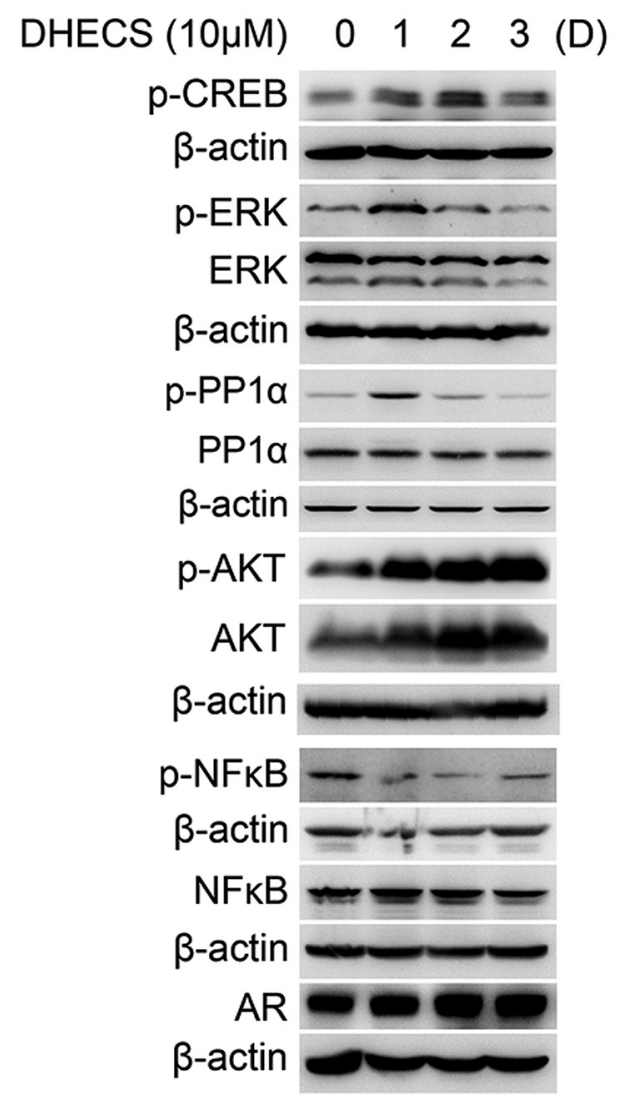

Figure 4. Effects of DHECSS on the expression of dopamine receptors and downstream signaling molecules. (A) Western bot analysis on the expression of DRD1,DRD2, $p$-CaMKK2, and p-AMPK in the docetaxel resistant C4-2B-TaxR cells treated with DHECS (15 $\mu M)$ at the indicated time points. (B) Western bot analysis on the expression of $p$-CREB, $p$-ERK, ERK, $p$-PP1 $\alpha, P P 1 \alpha, p-A K T, A K T, p-N F k B, N F k B$, and AR in C4-2BTaxR cells treated with DHECS $(10 \mu M)$ at the indicated time points.

dopamine receptor signaling is associated with the progression of human cancers, including PCa $(35,57-60)$. Some epidemiologic studies further suggested a correlation between psychotic disorders in which dopaminergic drugs are applied and the risk of cancer, of particular note, a reduced risk of PCa $(61,62)$. These observations have led to a hypothesis that certain dopaminergic drugs for neurological diseases can be repurposed to treat cancers (63). A previous report examined the in vitro effects of DHECS and several other ergot alkaloids in established human cancer cell lines and found that DHECS has a moderate cytotoxicity in PCa cell lines $\left(\log _{10} \mathrm{IC}_{50}=-5 \sim-4.5 \mathrm{M}\right)$ (64). In current study, we demonstrated a novel feature of DHECS, that is, DHECS is highly selective against chemoresistant $\mathrm{PCa}$ cells via the induction of cell cycle and programmed cell death. We further revealed that DHECS affects the expression of several key regulators of the cancer cell cycle and apoptosis, such as p53, RB, E2F1, survivin, Mcl-1, in chemoresistant PCa cells (Figure 5). To our knowledge, this is the first study investigating the cellular effect and mechanism of action of an ergot alkaloid in chemoresistant PCa cells.

A major challenge in drug repurposing for cancer therapy is to identify novel mechanisms of action and in many situations new target(s), of non-oncology drugs in cancer cells. Given the excellent in vitro cytotoxicity of DHECS in PCa cells and its high selectivity against chemoresistant cancer cells, we explored the underlying mechanism of DHECS. Several key regulators of the cancer cell cycle and apoptosis were found to be significantly affected by DHECS treatment, which may account for the observed cytotoxicity of DHECS in these cancer cells. For example, DHECS increased the expression of p53 and p21 and inhibited the expression of E2F1 and p-RB, which may subsequently result in the arrest at the $G_{1} / S$ checkpoint of the cell cycle. The suppression of survivin and Mcl-1, two critical survival factors implicated in therapeutic resistance, may contribute to DHECS-induced apoptosis. These molecular studies elucidated several new downstream effectors of DHECS in chemoresistant PCa cells. 


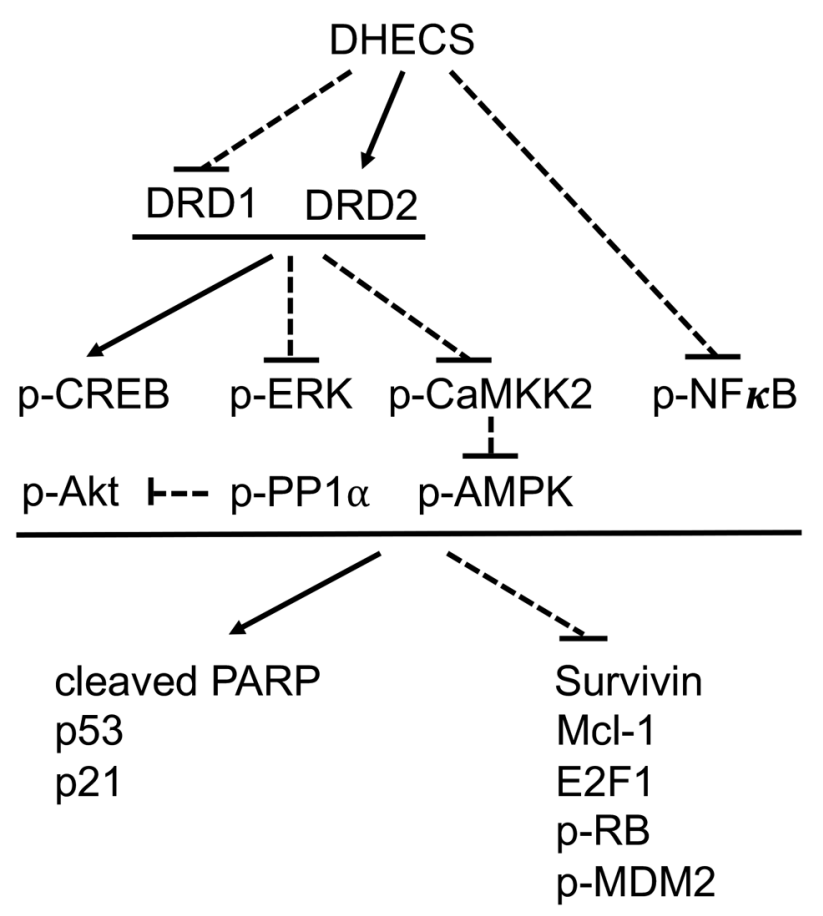

Figure 5. A schematic diagram of DHECS function in PCa cells. DHECS affects the expression of several key regulators of apoptosis and cell cycle through dopamine receptor-related pathways, thereby inducing apoptosis and cell cycle arrest in PCa cells. Solid lines represent the pathways potentially activated by DHECS, and dotted lines represent the pathways potentially inhibited by DHECS.

We further attempted to identify the signaling factors that directly mediate the effects of DHECS in chemoresistant $\mathrm{PCa}$ cells. In nerve cells, D1-like dopamine receptors stimulate whereas D2-like dopamine receptors suppress the activation of cAMP signaling, as demonstrated by the phosphorylation of CREB protein $(10,15,65)$. Our previous work has shown that the activation of CREB signaling is associated with invasive phenotypes of $\mathrm{PCa}$ and clinical bone metastasis, which indicated that CREB phosphorylation is a survival signal in PCa cells. Since DHECS is a known agonist of DRD2, we examined the effect of DHECS on DRD2 expression and CREB phosphorylation. DHECS increased DRD2 expression and reduced DRD1 expression in chemoresistant C4-2B-TaxR cells, suggesting that DHECS treatment may lead to the activation of DRD2 signaling and inactivation of DRD1 signaling. Interestingly, in contrast to our anticipations, DHECS treatment led to increased CREB phosphorylation instead of $\mathrm{p}$-CREB inhibition. These results suggested that the effects of DHECS on the expression of DRD1/DRD2 and CREB phosphorylation may be partially mediated by independent mechanisms. In other words, DHECS may activate cAMP-CREB signaling via a dopamine receptor-independent manner. However, given the excellent cytotoxicity of DHECS in chemoresistant PCa cells and the pro-survival role of CREB, it is plausible that the cAMP-CREB pathway may not be a major mediator of DHECS's cellular effects, and DHECS may act through other signaling molecules to exert its functions.

A possible mediator of DHECS functions in PCa cells could be CaMKK2, a serine/threonine protein kinase that is frequently upregulated in $\mathrm{PCa}$ and further overexpressed in metastatic castration-resistant tumors. Recent studies have proposed CaMKK2 as a direct target of androgen receptor (AR) and a potential driver of $\mathrm{PCa}$ progression, and the depletion of CaMKK2 suppresses cell proliferation, migration, invasion and tumor growth in preclinical models $(66,67)$. In prostate cells, CaMKK2 appeared to be the dominant kinase of AMPK, a master regulator of cellular homeostasis and tumor suppressor, by directly phosphorylating AMPK at Thr172 and activating AMPK (68, 69). Phosphorylation of CaMKK2 at Ser 155 by deathassociated protein kinase (DAPK) inhibits CaMKK2 activity $(70,71)$. Considering the effects of dopaminergic signaling on intracellular calcium levels and that the activation of CaMKK2 is dependent on calcium-mediated calmodulin (14), we investigated whether the CaMKK2-AMPK axis is responsive to DHECS treatment in $\mathrm{PCa}$ cells. Our data showed that DHECS simultaneously down-regulated pCaMKK2 (Ser511) and increased p-AMPK(Thr172) (Figure 4A), which may subsequently activate AMPK and elicit its function as a tumor suppressor. Supporting this notion, the DRD2 agonist aripiprazole induced AMPK phosphorylation and sensitized MCF-7 breast cancer cells to radiation therapy (53). Future mechanistical studies are needed to elucidate the role of DRD2, CaMKK2 and AMPK in mediating the effects of DHECS in chemoresistant PCa cells.

NF-kB plays essential roles in diverse biological processes, including inflammation and cancer (56). Activation of NF-kB signaling pathway promotes PCa progression and significantly correlates with advanced diseases (72). It has been shown that DRD2 activation suppresses nuclear translocation of NF-kB in the intracerebral hemorrhage mouse model, and DRD2 depletion retards non-small cell lung cancer progression through the inhibition of NF-kB $(54,55)$. NF-kB transcriptionally activates the expression of multiple oncogenic factors, including anti-apoptotic proteins survivin and Mcl-1 (73, 74). In chemoresistant PCa cells, DHECS treatment significantly inhibited NF-kB phosphorylation, an indicator of NF-kB-dependent transcriptional activity, which may contribute to the suppression of survivin and Mcl-1 and increased cell death.

AR plays a fundamental role in tumorigenesis and progression of $\mathrm{PCa}$ (75). Increased expression of $\mathrm{AR}$ and its variants, such as AR-V7, has been associated with therapeutic resistance and poor prognosis in patients receiving androgen- 
deprivation therapy (ADT) $(76,77)$. Loss of AR expression in $\mathrm{PCa}$ cells, possibly mediated by neuroendocrine differentiation, also promotes the progression to castration resistance $(78,79)$. Although DHECS did not significantly affect AR expression in PCa cells (Figure 4B), it is interesting to notice that DHECS had lower $\mathrm{IC}_{50}$ values in CWR22RV1 (AR- and AR-V7-positive, ADT-resistant) and PC-3 (ARnegative, ADT-resistant, neuroendocrine) cells than in LNCaP, C4-2 and C4-2B cells (expressing full-length AR). Considering DHECS also exhibited a high potency against chemoresistant C4-2B-TaxR cells, it is plausible to propose that DHECS could be an excellent drug candidate to specifically treat advanced $\mathrm{PCa}$, which is usually associated with castration-resistant and neuroendocrine phenotypes.

This study demonstrated that DHECS has excellent cytotoxicity in established PCa cells and intriguingly, more selectively targets PCa cells with aggressive phenotypes. Mechanistic studies indicated that DHECS may exert its inhibitory effect in chemoresistant PCa cells by affecting multiple signaling factors implicated in $\mathrm{PCa}$ progression. These results provide the first preclinical evidence supporting the hypothesis that DHECS is a novel inhibitor of aggressive PCa. Further preclinical and clinical investigation could allow the repositioning of DHECS as a safe and effective treatment for advanced PCa to overcome therapeutic resistance and improve clinical outcomes in $\mathrm{PCa}$ patients.

\section{Conflicts of Interest}

The Authors declare that there are no conflicts of interest regarding this study.

\section{Authors' Contributions}

LB and DW conceived and designed the project, LB, XL, XM and RZ acquired the data, LB and XL analyzed and interpreted the data, $\mathrm{XL}$ and DW wrote the paper.

\section{Acknowledgements}

This work was supported by Georgia Research Alliance VentureLab grant, Augusta University Georgia Cancer Center startup fund, Emory University Winship Cancer Institute Roswell Country Club Prostate Cancer Research Award (D. Wu), and the Department of Education Title III Program at Clark Atlanta University.

\section{References}

1 Siegel RL, Miller KD and Jemal A: Cancer statistics, 2020. CA: Cancer J Clin 70(1): 7-30, 2020. PMID: 31912902. DOI: $10.3322 /$ caac. 21590

2 Tannock IF, de Wit R, Berry WR, Horti J, Pluzanska A, Chi KN, Oudard S, Theodore C, James ND, Turesson I, Rosenthal MA, Eisenberger MA and Investigators TAX: Docetaxel plus prednisone or mitoxantrone plus prednisone for advanced prostate cancer. N Engl J Med 351(15): 1502-1512, 2004. PMID: 15470213. DOI: 10.1056/NEJMoa040720

3 Quinn DI, Sandler HM, Horvath LG, Goldkorn A and Eastham JA: The evolution of chemotherapy for the treatment of prostate cancer. Ann Oncol 28(11): 2658-2669, 2017. PMID: 29045523. DOI: $10.1093 /$ annonc/mdx348

4 Carlsson A, Lindqvist $M$ and Magnusson T: 3,4dihydroxyphenylalanine and 5-hydroxytryptophan as reserpine antagonists. Nature 180(4596): 1200, 1957. PMID: 13483658. DOI: $10.1038 / 1801200 \mathrm{a} 0$

5 Bjorklund A and Dunnett SB: Dopamine neuron systems in the brain: An update. Trends Neurosci 30(5): 194-202, 2007. PMID: 17408759. DOI: $10.1016 /$ j.tins.2007.03.006

6 Ehringer $\mathrm{H}$ and Hornykiewicz $\mathrm{O}$ : [distribution of noradrenaline and dopamine (3-hydroxytyramine) in the human brain and their behavior in diseases of the extrapyramidal system]. Klin Wochenschr 38: 1236-1239, 1960. PMID: 13726012. DOI: 10.1007/BF01485901.

7 Jakel RJ and Maragos WF: Neuronal cell death in huntington's disease: A potential role for dopamine. Trends Neurosci 23(6): 239-245, 2000. PMID: 10838590. DOI: 10.1016/s01662236(00)01568-x

8 Grace AA: Dysregulation of the dopamine system in the pathophysiology of schizophrenia and depression. Nat Rev Neurosci 17(8): 524-532, 2016. PMID: 27256556. DOI: $10.1038 / \mathrm{nrn} .2016 .57$

9 Andersen PH, Gingrich JA, Bates MD, Dearry A, Falardeau P, Senogles SE and Caron MG: Dopamine receptor subtypes: Beyond the d1/d2 classification. Trends Pharmacol Sci 11(6): 231-236, 1990. PMID: 2200181. DOI: 10.1016/0165-6147(90)90249-8

10 Usiello A, Baik JH, Rouge-Pont F, Picetti R, Dierich A, LeMeur M, Piazza PV and Borrelli E: Distinct functions of the two isoforms of dopamine d2 receptors. Nature 408(6809): 199-203, 2000. PMID: 11089973 . DOI: $10.1038 / 35041572$

11 Friedman E, Jin L-Q, Cai G-P, Hollon TR, Drago J, Sibley DR and Wang H-Y: D1-like dopaminergic activation of phosphoinositide hydrolysis is independent of d1a dopamine receptors: Evidence from d1a knockout mice. Mol Pharmacol 51(1): 6-11, 1997. PMID: 9016340. DOI: 10.1124/mol.51.1.6

12 Lee SP, So CH, Rashid AJ, Varghese G, Cheng R, Lança AJ, O'Dowd BF and George SR: Dopamine d1 and d2 receptor coactivation generates a novel phospholipase c-mediated calcium signal. J Biol Chem 279(34): 35671-35678, 2004. PMID: 15159403. DOI: $10.1074 /$ jbc.M401923200

13 Beaulieu J-M and Gainetdinov RR: The physiology, signaling, and pharmacology of dopamine receptors. Pharmacol Rev 63(1): 182-217, 2011. PMID: 21303898. DOI: 10.1124/pr.110.002642

14 Hernández-López S, Tkatch T, Perez-Garci E, Galarraga E, Bargas J, Hamm H and Surmeier DJ: D2 dopamine receptors in striatal medium spiny neurons reduce 1-type ca2+ currents and excitability via a novel plc $\beta 1$-ip3-calcineurin-signaling cascade. J Neurosci 20(24): 8987-8995, 2000. PMID: 11124974. DOI: 10.1523/JNEUROSCI.20-24-08987.2000

15 Valjent E, Pascoli V, Svenningsson P, Paul S, Enslen H, Corvol JC, Stipanovich A, Caboche J, Lombroso PJ, Nairn AC, Greengard P, Herve D and Girault JA: Regulation of a protein phosphatase cascade allows convergent dopamine and glutamate signals to activate erk in the striatum. Proc Natl Acad Sci USA 102(2): 491496, 2005. PMID: 15608059. DOI: 10.1073/pnas.0408305102 
16 Wang C, Buck DC, Yang R, Macey TA and Neve KA: Dopamine $\mathrm{d} 2$ receptor stimulation of mitogen-activated protein kinases mediated by cell type-dependent transactivation of receptor tyrosine kinases. J Neurochem 93(4): 899-909, 2005. PMID: 15857393. DOI: 10.1111/j.1471-4159.2005.03055.x

17 Popkin RJ: Dehydrogenated alkaloids of ergot in treatment of peripheral vascular diseases. Calif Med 72(2): 108-112, 1950. 1520028. PMID: 15408938.

18 Drago F, Valerio C, Scalisi B, D'Agata V and Scapagnini U: Dihydroergocristine and memory alterations of aged male rats. Pharmacol Biochem Behav 30(4): 961-965, 1988. PMID: 3147464. DOI: 10.1016/0091-3057(88)90127-x

19 Agliati G, Lazzaroni M, Mariani G, Marras F, Massetto N, Menozzi C, Ortenzi E, Perna G, Puppo N, Santambrogio S et al.: [one-year therapy with dihydroergocristine for treatment of impaired alertness and memory in elderly patients. Placebocontrolled multicenter study]. Arzneimittelforschung 42(11A): 1414-1416, 1992. PMID: 1492865.

20 Lazzaroni M, Cattalini C, Massetto N and Poli A: Dihydroergocristine in organic brain psychosyndrome. Multicenter placebocontrolled clinical double-blind study in 240 patients. Arzneimittelforschung 42(11A): 1410-1413, 1992. PMID: 1492864.

21 Boismare F, Le Poncin M and Lefrancois J: Biochemical and behavioural effects of hypoxic hypoxia in rats: Study of the protection afforded by ergot alkaloids. Gerontology 24: 6-13, 1978. PMID: 412730. DOI: 10.1159/000212292

22 Carruthers-Jones DI, Depoortere H and Loew DM: Changes in the rat electrocorticogram following administration of two dihydrogenated ergot derivatives. Gerontology 24: 23-33, 1978. PMID: 412729. DOI: 10.1159/000212295

23 Fiore L, Scapagnini $U$ and Canonico PL: Effect of dihydroergocryptine and dihydroergocristine on cyclic amp accumulation and prolactin release in vitro: Evidence for a dopaminomimetic action. Horm Res 25(3): 171-177, 1987. PMID: 3032757. DOI: 10.1159/000180649

24 Poli M, Cocchi D, Mailland F, Masu AM, Landi G, Craveri A and Muller EE: Prolactin lowering effect of dihydroergokryptine in rat and in man. J Endocrinol Invest 9(1): 31-36, 1986. PMID: 3084616. DOI: $10.1007 / \mathrm{BF} 03348059$

25 Calne DB, Shoulson I and Kartzinel R: An ergot derivative in the treatment of parkinson's disease. Postgrad Med J 52: 81-85, 1976. PMID: 183198.

26 Moracchini PV, Alfano G and Melandri F: Treatment of peripheral vascular diseases with dihydroergocristine. Minerva Cardioangiol 26(4): 277-290, 1978. PMID: 97601.

27 Schmidt A, Vetter W, Dennler HJ, Groll S and Orengo P: Combined uni- and multicenter double-blind studies in hypertensive patients. Comparison of blood pressure measurements. Schweiz Rundsch Med Prax 80(34): 849-855, 1991. PMID: 1925193.

28 Floss HG, Cassady JM and Robbers JE: Influence of ergot alkaloids on pituitary prolactin and prolactin-dependent processes. J Pharm Sci 62(5): 699-715, 1973. PMID: 4574586. DOI: $10.1002 /$ jps.2600620502

29 Rousseau JJ: Effects of a levo-5-hydroxytryptophandihydroergocristine combination on depression and neuropsychic performance: A double-blind placebo-controlled clinical trial in elderly patients. Clin Ther 9(3): 267-272, 1987. PMID: 3111702.

30 Coppi G: Dihydroergocristine. A review of pharmacology and toxicology. Arzneimittelforschung 42(11A): 1381-1390, 1992. PMID: 1492857.
31 Canonico PL: D-2 dopamine receptor activation reduces free [3h] arachidonate release induced by hypophysiotropic peptides in anterior pituitary cells. Endocrinology 125(3): 1180-1186, 1989. PMID: 2527149. DOI: 10.1210/endo-125-3-1180

32 Peters MA, Walenkamp AM, Kema IP, Meijer C, de Vries EG and Oosting SF: Dopamine and serotonin regulate tumor behavior by affecting angiogenesis. Drug Resist Updat 17(4-6): 96-104, 2014. PMID: 25269824. DOI: 10.1016/j.drup.2014.09.001

33 Bhat K, Saki M, Vlashi E, Cheng F, Duhachek-Muggy S, Alli C, Yu G, Medina P, He L, Damoiseaux R, Pellegrini M, Zemke NR, Nghiemphu PL, Cloughesy TF, Liau LM, Kornblum HI and Pajonk F: The dopamine receptor antagonist trifluoperazine prevents phenotype conversion and improves survival in mouse models of glioblastoma. Proc Natl Acad Sci USA, 2020. PMID: 32358191. DOI: 10.1073/pnas.1920154117

34 Leng ZG, Lin SJ, Wu ZR, Guo YH, Cai L, Shang HB, Tang H, Xue YJ, Lou MQ, Zhao W, Le WD, Zhao WG, Zhang X and Wu ZB: Activation of drd5 (dopamine receptor d5) inhibits tumor growth by autophagic cell death. Autophagy 13(8): 1404-1419, 2017. PMID: 28613975. DOI: 10.1080/15548627.2017.1328347

35 Yang Y, Mamouni K, Li X, Chen Y, Kavuri S, Du Y, Fu H, Kucuk $\mathrm{O}$ and Wu D: Repositioning dopamine d2 receptor agonist bromocriptine to enhance docetaxel chemotherapy and treat bone metastatic prostate cancer. Mol Cancer Ther 17(9): 1859-1870, 2018. PMID: 29907594. DOI: 10.1158/15357163.MCT-17-1176

36 Zhang S, Wang X, Osunkoya AO, Iqbal S, Wang Y, Chen Z, Muller S, Chen Z, Josson S, Coleman IM, Nelson PS, Wang YA, Wang R, Shin DM, Marshall FF, Kucuk O, Chung LW, Zhau HE and $\mathrm{Wu} \mathrm{D}$ : Eplin downregulation promotes epithelialmesenchymal transition in prostate cancer cells and correlates with clinical lymph node metastasis. Oncogene 30(50): 49414952, 2011. PMID: 21625216. DOI: 10.1038/onc.2011.199

37 Zhu Y, Liu C, Nadiminty N, Lou W, Tummala R, Evans CP and Gao AC: Inhibition of abcb1 expression overcomes acquired docetaxel resistance in prostate cancer. Mol Cancer Ther 12(9): 1829-1836, 2013. 3947549. PMID: 23861346. DOI: 10.1158/1535-7163.MCT-13-0208

38 Wang X, Beitler JJ, Wang H, Lee MJ, Huang W, Koenig L, Nannapaneni S, Amin AR, Bonner M and Shin HJC: Honokiol enhances paclitaxel efficacy in multi-drug resistant human cancer model through the induction of apoptosis. PLoS One 9(2), 2014. PMID: 24586249. DOI: 10.1371/journal.pone.0086369

39 Wu J, Ling X, Pan D, Apontes P, Song L, Liang P, Altieri DC, Beerman T and Li F: Molecular mechanism of inhibition of survivin transcription by the gc-rich sequence-selective DNA binding antitumor agent, hedamycin: Evidence of survivin down-regulation associated with drug sensitivity. J Biol Chem 280(10): 9745-9751, 2005. PMID: 15637054. DOI: 10.1074/ jbc.M409350200

40 Zhang S, Wang X, Iqbal S, Wang Y, Osunkoya AO, Chen Z, Chen Z, Shin DM, Yuan H, Wang YA, Zhau HE, Chung LW, Ritenour C, Kucuk $\mathrm{O}$ and $\mathrm{Wu}$ D: Epidermal growth factor promotes protein degradation of epithelial protein lost in neoplasm (eplin), a putative metastasis suppressor, during epithelial-mesenchymal transition. J Biol Chem 288(3): 14691479, 2013. PMID: 23188829. DOI: 10.1074/jbc.M112.438341

41 Yang JM, Chin KV and Hait WN: Interaction of p-glycoprotein with protein kinase $\mathrm{c}$ in human multidrug resistant carcinoma cells. Cancer Res 56(15): 3490-3494, 1996. PMID: 8758935. 
42 Kastan MB and Bartek J: Cell-cycle checkpoints and cancer. Nature 432(7015): 316-323, 2004. PMID: 15549093. DOI: 10.1038/nature03097

43 Bertoli C, Skotheim JM and de Bruin RA: Control of cell cycle transcription during $\mathrm{g} 1$ and s phases. Nat Rev Mol Cell Biol 14(8): 518-528, 2013. PMID: 23877564. DOI: $10.1038 / \mathrm{nrm} 3629$.

44 Grana X, Garriga J and Mayol X: Role of the retinoblastoma protein family, prb, p107 and p130 in the negative control of cell growth. Oncogene 17(25): 3365-3383, 1998. PMID: 9916999. DOI: $10.1038 /$ sj.onc. 1202575

45 Motwani M, Jung C, Sirotnak FM, She Y, Shah MA, Gonen M and Schwartz GK: Augmentation of apoptosis and tumor regression by flavopiridol in the presence of cpt-11 in het116 colon cancer monolayers and xenografts. Clin Cancer Res 7(12): 4209-4219, 2001. PMID: 11751522.

46 Brooks CL and Gu W: P53 ubiquitination: Mdm2 and beyond. Mol Cell 21(3): 307-315, 2006. PMID: 16455486. DOI: 10.1016/j.molcel.2006.01.020

47 Seo SI, Gera L, Zhau HE, Qian WP, Iqbal S, Johnson NA, Zhang S, Zayzafoon M, Stewart J, Wang R, Chung LW and Wu D: Bkm1740, an acyl-tyrosine bisphosphonate amide derivative, inhibits the bone metastatic growth of human prostate cancer cells by inducing apoptosis. Clin Cancer Res 14(19): 6198-6206, 2008. PMID: 18829499. DOI: 10.1158/1078-0432.CCR-08-1023

48 Tolcher AW, Quinn DI, Ferrari A, Ahmann F, Giaccone G, Drake T, Keating A and de Bono JS: A phase ii study of ym155, a novel small-molecule suppressor of survivin, in castrationresistant taxane-pretreated prostate cancer. Ann Oncol 23(4): 968-973, 2012. PMID: 21859898. DOI: 10.1093/annonc/mdr353

49 Krajewska M, Krajewski S, Epstein JI, Shabaik A, Sauvageot J, Song K, Kitada S and Reed JC: Immunohistochemical analysis of bcl-2, bax, bcl-x, and mcl-1 expression in prostate cancers. Am J Pathol148(5): 1567, 1996. PMID: 8623925.

50 Zhang S, Zhau HE, Osunkoya AO, Iqbal S, Yang X, Fan S, Chen Z, Wang R, Marshall FF and Chung LW: Vascular endothelial growth factor regulates myeloid cell leukemia-1 expression through neuropilin-1-dependent activation of c-met signaling in human prostate cancer cells. Mol Cancer 9(1): 9, 2010. PMID: 20085644. DOI: 10.1186/1476-4598-9-9

51 Chen Y, Gera L, Zhang S, Li X, Yang Y, Mamouni K, Wu AY, Liu H, Kucuk O and Wu D: Small molecule bkm1972 inhibits human prostate cancer growth and overcomes docetaxel resistance in intraosseous models. Cancer Lett 446: 62-72, 2019. PMID: 30660650. DOI: 10.1016/j.canlet.2019.01.010

52 Beaulieu JM and Gainetdinov RR: The physiology, signaling, and pharmacology of dopamine receptors. Pharmacol Rev 63(1): 182-217, 2011. PMID: 21303898. DOI: 10.1124/pr.110.002642

53 Lee H, Kang S, Sonn JK and Lim YB: Dopamine receptor d2 activation suppresses the radiosensitizing effect of aripiprazole via activation of ampk. FEBS Open Bio 9(9): 1580-1588, 2019. PMID: 31301124. DOI: 10.1002/2211-5463.12699

$54 \mathrm{Wu}$ XY, Zhang CX, Deng LC, Xiao J, Yuan X, Zhang B, Hou ZB, Sheng ZH, Sun L, Jiang QC and Zhao W: Overexpressed d2 dopamine receptor inhibits non-small cell lung cancer progression through inhibiting nf-kappab signaling pathway. Cell Physiol Biochem 48(6): 2258-2272, 2018. PMID: 30114693. DOI: $10.1159 / 000492644$

55 Zhang Y, Chen Y, Wu J, Manaenko A, Yang P, Tang J, Fu W and Zhang JH: Activation of dopamine $\mathrm{d} 2$ receptor suppresses neuroinflammation through alphab-crystalline by inhibition of nf-kappab nuclear translocation in experimental ich mice model. Stroke 46(9): 2637-2646, 2015. PMID: 26251254. DOI: 10.1161/STROKEAHA.115.009792

56 Tyagi $M$ and Patro BS: Salinomycin reduces growth, proliferation and metastasis of cisplatin resistant breast cancer cells via nf-kb deregulation. Toxicol In Vitro 60: 125-133, 2019. PMID: 31077746. DOI: 10.1016/j.tiv.2019.05.004

57 Akbarian F, Abolhasani M, Dadkhah F, Asadi F and Ahangari G: Novel insight into differential gene expression and clinical significance of dopamine receptors, comt, and il6 in bph and prostate cancer. Curr Mol Med 19(8): 605-619, 2019. PMID: 31288722. DOI: $10.2174 / 1566524019666190709180146$

58 Stein MN, Malhotra J, Tarapore RS, Malhotra U, Silk AW, Chan N, Rodriguez L, Aisner J, Aiken RD and Mayer T: Safety and enhanced immunostimulatory activity of the drd2 antagonist onc201 in advanced solid tumor patients with weekly oral administration. J Immunother Cancer 7(1): 136, 2019. PMID: 31118108. DOI: 10.1186/s40425-019-0599-8

59 Wang X, Wang ZB, Luo C, Mao XY, Li X, Yin JY, Zhang W, Zhou HH and Liu ZQ: The prospective value of dopamine receptors on bio-behavior of tumor. J Cancer 10(7): 1622-1632, 2019. PMID: 31205518 . DOI: $10.7150 /$ jca. 27780

60 Weissenrieder JS, Neighbors JD, Mailman RB and Hohl RJ: Cancer and the dopamine d2 receptor: A pharmacological perspective. J Pharmacol Exp Ther 370(1): 111-126, 2019. PMID: 31000578. DOI: 10.1124/jpet.119.256818

61 Lin GM, Chen YJ, Kuo DJ, Jaiteh LE, Wu YC, Lo TS and Li YH: Cancer incidence in patients with schizophrenia or bipolar disorder: A nationwide population-based study in taiwan, 19972009. Schizophr Bull 39(2): 407-416, 2013. PMID: 22045828. DOI: $10.1093 / \mathrm{schbul} / \mathrm{sbr} 162$

62 Dalton SO, Mellemkjaer L, Thomassen L, Mortensen PB and Johansen C: Risk for cancer in a cohort of patients hospitalized for schizophrenia in denmark, 1969-1993. Schizophr Res 75: 2-3): 315324, 2005. PMID: 15885523. DOI: 10.1016/j.schres.2004.11.009

63 Brown AS and Patel CJ: A standard database for drug repositioning. Sci Data 4: 170029, 2017. PMID: 28291243. DOI: 10.1038/sdata.2017.29

64 Mrusek M, Seo EJ, Greten HJ, Simon M and Efferth T: Identification of cellular and molecular factors determining the response of cancer cells to six ergot alkaloids. Invest New Drugs 33(1): 32-44, 2015. PMID: 25342140. DOI: 10.1007/s10637014-0168-4

65 Zhang L, Lou D, Jiao H, Zhang D, Wang X, Xia Y, Zhang J and $\mathrm{Xu} \mathrm{M}$ : Cocaine-induced intracellular signaling and gene expression are oppositely regulated by the dopamine $\mathrm{d} 1$ and $\mathrm{d} 3$ receptors. J Neurosci 24(13): 3344-3354, 2004. PMID: 15056714. DOI: 10.1523/JNEUROSCI.0060-04.2004

66 Massie CE, Lynch A, Ramos-Montoya A, Boren J, Stark R, Fazli L, Warren A, Scott H, Madhu B, Sharma N, Bon H, Zecchini V, Smith DM, Denicola GM, Mathews N, Osborne M, Hadfield J, Macarthur S, Adryan B, Lyons SK, Brindle KM, Griffiths J, Gleave ME, Rennie PS, Neal DE and Mills IG: The androgen receptor fuels prostate cancer by regulating central metabolism and biosynthesis. EMBO J 30(13): 2719-2733, 2011. PMID: 21602788. DOI: $10.1038 /$ emboj.2011.158

67 Frigo DE, Howe MK, Wittmann BM, Brunner AM, Cushman I, Wang Q, Brown M, Means AR and McDonnell DP: Cam kinase kinase beta-mediated activation of the growth regulatory kinase 
ampk is required for androgen-dependent migration of prostate cancer cells. Cancer Res 71(2): 528-537, 2011. PMID: 21098087. DOI: 10.1158/0008-5472.CAN-10-2581

68 Hawley SA, Pan DA, Mustard KJ, Ross L, Bain J, Edelman AM, Frenguelli BG and Hardie DG: Calmodulin-dependent protein kinase kinase- $\beta$ is an alternative upstream kinase for ampactivated protein kinase. Cell Metabol 2(1): 9-19, 2005. PMID: 16054095. DOI: 10.1016/j.cmet.2005.05.009

69 Khan AS and Frigo DE: A spatiotemporal hypothesis for the regulation, role, and targeting of ampk in prostate cancer. Nat Rev Urol 14(3): 164-180, 2017. PMID: 28169991. DOI: 10.1038/nrurol.2016.272

70 Schumacher AM, Schavocky JP, Velentza AV, Mirzoeva S and Watterson DM: A calmodulin-regulated protein kinase linked to neuron survival is a substrate for the calmodulin-regulated deathassociated protein kinase. Biochemistry 43(25): 8116-8124, 2004. PMID: 15209507. DOI: $10.1021 /$ bi049589v

71 MacDonald AF, Bettaieb A, Donohoe DR, Alani DS, Han A, Zhao $\mathrm{Y}$ and Whelan $\mathrm{J}$ : Concurrent regulation of $1 \mathrm{~kb} 1$ and camkk2 in the activation of ampk in castrate-resistant prostate cancer by a well-defined polyherbal mixture with anticancer properties. BMC Complement Altern Med 18(1): 188, 2018. PMID: 29914450. DOI: 10.1186/s 12906-018-2255-0

72 Jain G, Cronauer MV, Schrader M, Moller P and Marienfeld RB: Nf-kappab signaling in prostate cancer: A promising therapeutic target? World J Urol 30(3): 303-310, 2012. PMID: 22085980. DOI: $10.1007 / \mathrm{s} 00345-011-0792-y$

73 Angileri FF, Aguennouz M, Conti A, La Torre D, Cardali S, Crupi R, Tomasello C, Germano A, Vita G and Tomasello F: Nuclear factor-kappab activation and differential expression of survivin and bcl-2 in human grade 2-4 astrocytomas. Cancer 112(10): 2258-2266, 2008. PMID: 18327814. DOI: 10.1002/cncr.23407

74 Liu H, Yang J, Yuan Y, Xia Z, Chen M, Xie L, Ma X, Wang J, Ouyang S, Wu Q, Yu F, Zhou X, Yang Y, Cao Y, Hu J and Yin B: Regulation of mcl-1 by constitutive activation of nf-kappab contributes to cell viability in human esophageal squamous cell carcinoma cells. BMC Cancer 14: 98, 2014. PMID: 24529193. DOI: $10.1186 / 1471-2407-14-98$
75 Davey RA and Grossmann M: Androgen receptor structure, function and biology: From bench to bedside. Clin Biochem Rev 37(1): 3-15, 2016. PMID: 27057074.

76 Hornberg E, Ylitalo EB, Crnalic S, Antti H, Stattin P, Widmark A, Bergh A and Wikstrom P: Expression of androgen receptor splice variants in prostate cancer bone metastases is associated with castration-resistance and short survival. PLoS One 6(4): e19059, 2011. PMID: 21552559. DOI: 10.1371/journal.pone.0019059

77 Scher HI, Graf RP, Schreiber NA, McLaughlin B, Lu D, Louw J, Danila DC, Dugan L, Johnson A, Heller G, Fleisher M and Dittamore R: Nuclear-specific ar-v7 protein localization is necessary to guide treatment selection in metastatic castrationresistant prostate cancer. Eur Urol 71(6): 874-882, 2017. PMID: 27979426. DOI: 10.1016/j.eururo.2016.11.024

78 Aggarwal R, Zhang T, Small EJ and Armstrong AJ: Neuroendocrine prostate cancer: Subtypes, biology, and clinical outcomes. J Natl Compr Canc Netw 12(5): 719-726, 2014. PMID: 24812138. DOI: 10.6004/jncen.2014.0073

79 Komiya A, Yasuda K, Watanabe A, Fujiuchi Y, Tsuzuki T and Fuse H: The prognostic significance of loss of the androgen receptor and neuroendocrine differentiation in prostate biopsy specimens among castration-resistant prostate cancer patients. Mol Clin Oncol 1(2): 257-262, 2013. PMID: 24649157. DOI: $10.3892 / \mathrm{mco} .2013 .69$

Received September 22, 2020

Revised September 30, 2020 Accepted October 1, 2020 